\title{
Patient Satisfaction and Experiences towards Paramedical Services in a Secondary Care Referral Healthcare Setting of India
}

\author{
Sahithi Bogireddy ${ }^{1 *}$, Mohanraj Rathinaveluํ, Rajeswari Kalimuthu², Yiragamreddy Padmanabha \\ Reddy $^{3}$ \\ ${ }^{1}$ Department of Pharmacy Practice, Raghavendra Institute of Pharmaceutical Education and Research-RIPER, Anantapuramu, Andhra \\ Pradesh, INDIA. \\ ${ }^{2}$ Department of Pharmacy Practice, Krupanidhi College of Pharmacy, Bangalore, Karnataka, INDIA. \\ ${ }^{3}$ Raghavendra Institute of Pharmaceutical Education and Research-RIPER, Anantapuramu, Andhra Pradesh, INDIA.
}

\begin{abstract}
Background: Healthcare organization is a sector where patient is the main focus where improving the patient outcome is the imperative function. Patient satisfaction survey helps in evaluating the quality of the services provided by the hospital. Objective: The current prospective observational (survey-based) study of six months duration aimed in evaluating the patient experience and satisfaction towards the paramedical services provided in a healthcare setting of south India. Methods: A standard and validated questionnaire on paramedical services was designed consisting of 32 questions reviewed by the nurses and pharmacists, for the simplicity, reliability and clear understanding of the patients relating to various aspects that influence the patient satisfaction.

The questions had been scored ranging from 1-5 based on the satisfaction levels. A proper information consent was made during data collection by clearly explaining the patients about the study. Results: In 250 patients, the study participant responded $49.2 \%$ of satisfaction towards patient centered pharmaceutical care services, $43.6 \%$ of satisfaction towards nursing care service, $52 \%$ and $53.6 \%$ of satisfactory level towards nutrition and laboratory services respectively. In our study, the overall response of the patient about paramedical services was satisfactorial. Conclusion: In conclusion, the principles of patient centered paramedical care services has to be implemented and practiced to achieve better health outcome and patient satisfaction.
\end{abstract}

Key words: Patient satisfaction survey, Paramedical care services, Nutritional services, Nursing care services, Pharmaceutical care services, Survey.

\section{INTRODUCTION}

Patient satisfaction is a multifaceted concept that reflects the quality and type of the services provided by the healthcare professionals/providers, and to see how well it has been delivered, and the extent to which the needs and expectations of the patients are met. Patient satisfaction, as an indicator of performance has been defined as the self-evaluation of healthcare professionals/ providers and services. ${ }^{1}$ It allows an assessment on the services provided which directly reflects the patients' perspective and also serves as a connection between the needs and desires of the patients and the services provided. ${ }^{2}$ Pascoe (1983) explained patient satisfaction as a reaction of the healthcare recipient's to the salient features of the process, context and result of the experience to the services provided by the healthcare professionals/providers. ${ }^{3}$

Submitted date : $26 / 12 / 2015$

Accepted date : 13/01/2016

DOI: 10.5530/ijopp.9.1.8

Address for

correspondence:

Dr. Sahithi Bogireddy,

Pharm. D,

Assistant Professor,

Department of Pharmacy

Practice,

Raghavendra Institute of

Pharmaceutical Education and

Research-RIPER,

Anantapuramu, Andhra

Pradesh, INDIA

Ph no:+91 8121934940

E-mail:moley4u@rediffmail.

com

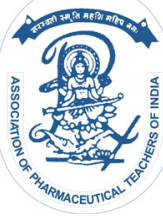

www.ijopp.org 
The most serious challenge in the developing countries for healthcare services is to identify various ways to create them as a more patient-oriented. Patient-centered care may improve outcomes of the treatment, and the main attention of local and national efforts is to optimize the health and healthcare delivery by implementing the patient centered care. One of the pillars in the patient- centered care is the satisfaction of the patient with care.

Now-a-days, the traditional practice of the hospital pharmacist from a dispenser has been changing to the bedside patient care and pharmaceutical care planning. ${ }^{4,5}$ Pharmaceutical care is a professional practice, in which the main beneficiary is the patient. This practice includes the responsible provision of pharmacotherapy to attain certain outcomes associated with the improvement in health of the patients and their quality of life. ${ }^{6,7}$

Furthermore, varying from the past a multidisciplinary healthcare team (i.e. physician, nurse, pharmacist and associated healthcare professionals) approach is adopted for the treatment of the patient. ${ }^{4,5}$ Nursing care has always been focused to maintain people healthy, to provide ease, care and assurance to the patients. ${ }^{8}$ As nurses are involved in each and every part of the patient care in the hospital the 'nursing care' is considered to be a key factor on which the satisfaction of the patient is depended. ${ }^{?}$

Patient satisfaction is regarded as a self-assessment or appraisal of the service or product received. ${ }^{1,3,10}$ Data acquired from a patient satisfaction survey can be used for various purposes, such as the recognizing of potential areas to improve healthcare services, ${ }^{10}$ the differentiation of the quality of various care programs and systems, and the reorganization of the patients who are willing to disenroll from healthcare plans. ${ }^{11}$

Thus, patient satisfaction data can assist as an indicator of the quality of the service provided and as a predictor of behaviour associated with health. ${ }^{3}$

Regardless the consensus the satisfaction of the patients regarding the services is crucial for assuring the quality in hospitals and medical services; there is a lack of empirical evidence on approval of the healthcare practice by the consumers. ${ }^{12}$

The present study aims to assess the patient satisfaction about the paramedical services provided to the patients at study site and also evaluates the services and other amenities provided in the hospital that affects the patient satisfaction and tries to identify the areas that has to be improved to increase the patient satisfaction.

\section{MATERIALS AND METHODS}

Study Design: Prospective, observational survey study Study Duration: Six months (May-October 2015)

Study Site: Departments of General Medicine, Surgery, Obstetrics and Gynaecology and Out-patient Department of a 300 bedded secondary care referral hospital in south India.

Study population: 250 patients

\section{Inclusion Criteria}

- All patients of either gender who were admitted to the study site during study period and were willing to participate in the study.

- All patients who were visited to the out-patient department during study period and were willing to participate in the study.

\section{Exclusion Criteria}

- Patients who were not able to give their opinion i.e. paediatric patients, unconscious patients, psychiatric patients.

- The patients who were all unwilling to participate in the study.

Study Procedure: The proposed study was planned and carried out in three phases mentioned below.

\section{Phase- I:}

- Submission of the protocol and obtaining consent from the hospital authority.

- Literature survey.

- Development and evaluation of questionnaire for the patient satisfaction survey.

- Designing of the patient information and consent form.

\section{Phase-II:}

- Data collection through the questionnaire for patient satisfaction survey.

- Literature survey.

- Data analysis.

- Evaluate the satisfaction levels of the patients.

- Application of statistical tools.

\section{Phase-III:}

- Literature survey and data analysis.

- Preparation and submission of reports.

\section{Consent from Hospital authority}

A proforma of the study which included the objectives, methodology was submitted to the hospital authority for approval. The approval from the hospital was procured through the letter. The author was permitted to utilize hospital facilities for conducting the survey. 


\section{Literature survey}

An extensive literature survey was performed regarding the different aspects of the patient satisfaction survey as it is one of the developing corners for the evaluation of the healthcare. The literature supporting the study was gathered from various sources such as:

- International Journal of Medical Science and Public Health.

- International Journal of Research and Development of Health.

- International Journal for Quality in Healthcare.

- Global Journal of Health Sciences.

- American Journal of Medicine and Medical Sciences.

- Indian Journal of Community Health.

- Research in Social and Administrative Pharmacy.

- Quality and Safety in Healthcare.

- Nursing and Midwifery in Healthcare.

\section{Design of patient information form}

A patient information form was designed, to inform the patients or the care givers about the purpose and the necessity of the study and to assure them that the confidentiality will be strictly maintained and also it helps in improving the patients' health.

\section{Patient consent form}

A patient consent form was prepared and written consent was collected from all the patients or from the caregivers by using the patient consent form after providing the information format.

\section{Development of the questionnaire}

To evaluate the patient satisfaction a questionnaire was developed relating to the paramedical services. The questionnaire was designed by considering the local settings.

It consisted of 32 questions which relates to various aspects that influence the patient satisfaction, and also three open ended questions to obtain information about their experience in the hospital and also to give their suggestions which they feel necessary to implement in the hospital settings. The questions had been scored ranging from 1-5 based on the satisfaction levels i.e., from very unsatisfied to very satisfied. The questionnaire developed has been reviewed by the nurses and pharmacists, for the simplicity, reliability and to check the understanding level of the patients.

\section{Data collection and Analysis}

The data has been collected from the patients through the face-to-face interview to complete the questionnaire while the patient is going to be discharged. During data collection, patients were informed about the study using patient information format and obtained their written consent either from the patients or their caregivers. The data was analyzed using the descriptive statistics.

\section{RESULTS}

The present study involved 250 patients among which 141 were female and 109 were male. Demographic details of the study participants was categorized based on gender distribution, age distribution and department wise distribution, the results of which were thoroughly analyzed and reported in Table 1 (Demography distribution of the patients). The responses of satisfactory levels of the patients towards pharmaceutical care services is assessed and reported in Table 2 (Patients satisfaction towards pharmaceutical care services). The satisfactory levels of the patient regarding the nursing care services provided in the hospital have been mentioned in the Table 3 (Patients satisfaction towards nursing care services). The satisfactory levels of the patient regarding the allied Healthcare Services and hospital infrastructure are mentioned in the Table 4. The overall satisfactory levels and experiences of the patient regarding the paramedical services provided in the hospital have been mentioned in the Table 5 (Overall patients' satisfaction and experiences on paramedical Services).

\section{DISCUSSION}

To the best of our knowledge, this was the first study in India that evaluated patients' experiences and satisfaction towards paramedical services in a healthcare setting. In our study, the participation rate was higher than a similar study where study participants were $220(88 \%)$ regarding the pharmaceutical care satisfaction of patients at a public hospital in Qatar (Khudair IF et al., 2013). ${ }^{13}$ The finding of our study regarding the patient satisfaction towards pharmaceutical care services on patient counseling and the dispensary services was similar to the study mentioned above in Qatar ${ }^{13}$ were patient satisfaction is positively influenced by service promptness, pharmacist attitude, medication counseling, pharmacy location and waiting area.

Satisfaction levels regarding quality of nursing care services in the patients were also found to be high as most of the patients were satisfied with the timely administration of drugs, timely response in emergency condition, empathetical and professional behaviour, importance to patient privacy and counseling given by nurses in our study which was found in a similar study carried in a tertiary care medical college hospital in Punjab, North India (Sumeet Singh et al., 2013). ${ }^{14}$ In our study the 
Table 1: Demographical Distribution of the Patients

\begin{tabular}{|c|c|c|c|c|c|}
\hline \multicolumn{2}{|c|}{$\begin{array}{l}\text { Age wise distribution } \\
\text { (in years) }\end{array}$} & $18-25$ & $26-40$ & $41-60$ & $>60$ \\
\hline \multicolumn{2}{|c|}{ Number of patients } & 48 & 73 & 93 & 36 \\
\hline \multicolumn{6}{|c|}{ Gender wise distribution } \\
\hline \multicolumn{2}{|c|}{ Male } & 9 & 27 & 52 & 21 \\
\hline \multicolumn{2}{|c|}{ Female } & 39 & 46 & 41 & 15 \\
\hline \multicolumn{6}{|c|}{ Department wise distribution } \\
\hline \multirow{2}{*}{$\begin{array}{l}\text { General } \\
\text { Medicine }\end{array}$} & MMW & 4 & 6 & 16 & 6 \\
\hline & FMW & 2 & 8 & 11 & 3 \\
\hline \multirow{2}{*}{$\begin{array}{l}\text { General } \\
\text { Surgery }\end{array}$} & MSW & 3 & 7 & 9 & 4 \\
\hline & FSW & 1 & 5 & 12 & 3 \\
\hline \multicolumn{2}{|c|}{ Gynaecology } & 26 & 21 & 6 & 1 \\
\hline \multirow[t]{2}{*}{ Out-Patient } & Male & 2 & 14 & 27 & 11 \\
\hline & Female & 10 & 12 & 12 & 8 \\
\hline
\end{tabular}

\begin{tabular}{|c|c|c|c|c|c|c|}
\hline \multirow[b]{2}{*}{ S.No } & \multirow{2}{*}{$\begin{array}{l}\text { Pharmaceutical } \\
\text { Services }\end{array}$} & \multicolumn{5}{|c|}{ Satisfaction Level } \\
\hline & & 5 & 4 & 3 & 2 & 1 \\
\hline 01. & Dispensary Services & $\begin{array}{c}26 \\
(10.4 \%)\end{array}$ & $\begin{array}{c}127 \\
(50.8 \%)\end{array}$ & $\begin{array}{c}89 \\
(35.6 \%)\end{array}$ & $\begin{array}{c}7 \\
(2.8 \%)\end{array}$ & $\begin{array}{c}1 \\
(0.4 \%)\end{array}$ \\
\hline 02. & $\begin{array}{l}\text { Time taken for } \\
\text { Dispensing }\end{array}$ & $\begin{array}{c}29 \\
(11.6 \%)\end{array}$ & $\begin{array}{c}51 \\
(20.4 \%)\end{array}$ & $\begin{array}{c}128 \\
(51.2 \%)\end{array}$ & $\begin{array}{c}36 \\
(14.4 \%)\end{array}$ & $\begin{array}{c}6 \\
(2.4 \%)\end{array}$ \\
\hline 03. & Patient Counseling & $\begin{array}{c}29 \\
(11.6 \%)\end{array}$ & $\begin{array}{c}106 \\
(42.4 \%)\end{array}$ & $\begin{array}{c}102 \\
(40.8 \%)\end{array}$ & $\begin{array}{c}8 \\
(3.2 \%)\end{array}$ & $\begin{array}{c}5 \\
(02 \%)\end{array}$ \\
\hline 04. & $\begin{array}{c}\text { Empathetical and } \\
\text { Professional behaviour }\end{array}$ & $\begin{array}{c}42 \\
(16.8 \%)\end{array}$ & $\begin{array}{c}103 \\
(41.2 \%)\end{array}$ & $\begin{array}{c}92 \\
(36.8 \%)\end{array}$ & $\begin{array}{c}11 \\
(4.4 \%)\end{array}$ & $\begin{array}{c}2 \\
(0.8 \%)\end{array}$ \\
\hline 05. & $\begin{array}{c}\text { Importance to Patient } \\
\text { Privacy }\end{array}$ & $\begin{array}{c}45 \\
(18 \%)\end{array}$ & $\begin{array}{c}103 \\
(41.2 \%)\end{array}$ & $\begin{array}{c}79 \\
(31.6 \%)\end{array}$ & $\begin{array}{c}15 \\
(06 \%)\end{array}$ & $\begin{array}{c}8 \\
(3.2 \%)\end{array}$ \\
\hline 06. & $\begin{array}{l}\text { Quality of the } \\
\text { pharmaceutical } \\
\text { services. }\end{array}$ & $\begin{array}{c}47 \\
(18.8 \%)\end{array}$ & $\begin{array}{c}111 \\
(44.4 \%)\end{array}$ & $\begin{array}{c}56 \\
(22.4 \%)\end{array}$ & $\begin{array}{c}35 \\
(14 \%)\end{array}$ & $\begin{array}{c}1 \\
(0.4 \%)\end{array}$ \\
\hline
\end{tabular}

(NOTE: 5-Very Satisfied, 4-Satisfied, 3-OK, 2-Unsatisfied, 1-Very Unsatisfied).

\section{Table 3: Patients satisfaction towards nursing care services}

\begin{tabular}{|c|c|c|c|c|c|c|}
\hline \multirow[b]{2}{*}{ S.No } & \multirow[b]{2}{*}{ Nursing Services } & \multicolumn{5}{|c|}{ Satisfaction Level } \\
\hline & & 5 & 4 & 3 & 2 & 1 \\
\hline 01. & Patient Counseling & $\begin{array}{c}54 \\
(21.6 \%)\end{array}$ & $\begin{array}{c}139 \\
(55.6 \%)\end{array}$ & $\begin{array}{c}46 \\
(18.4 \%)\end{array}$ & $\begin{array}{c}10 \\
(04 \%)\end{array}$ & $\begin{array}{c}1 \\
(0.4 \%)\end{array}$ \\
\hline 02. & $\begin{array}{c}\text { Timely Administration } \\
\text { of Drugs }\end{array}$ & $\begin{array}{c}69 \\
(27.6 \%)\end{array}$ & $\begin{array}{c}130 \\
(52 \%)\end{array}$ & $\begin{array}{c}47 \\
(18.8 \%)\end{array}$ & $\begin{array}{c}4 \\
(1.6 \%)\end{array}$ & 0 \\
\hline 03. & $\begin{array}{c}\text { Timely Response in } \\
\text { Emergency }\end{array}$ & $\begin{array}{c}107 \\
(42.8 \%)\end{array}$ & $\begin{array}{c}99 \\
(39.6 \%)\end{array}$ & $\begin{array}{c}42 \\
(16.8 \%)\end{array}$ & $\begin{array}{c}2 \\
(0.8 \%)\end{array}$ & 0 \\
\hline 04. & $\begin{array}{c}\text { Empathetical } \\
\text { and Professional } \\
\text { behaviour }\end{array}$ & $\begin{array}{c}53 \\
(21.2 \%)\end{array}$ & $\begin{array}{c}96 \\
(38.4 \%)\end{array}$ & $\begin{array}{c}98 \\
(39.2 \%)\end{array}$ & $\begin{array}{c}2 \\
(0.8 \%)\end{array}$ & $\begin{array}{c}1 \\
(0.4 \%)\end{array}$ \\
\hline 05. & $\begin{array}{c}\text { Importance to Patient } \\
\text { Privacy }\end{array}$ & $\begin{array}{c}43 \\
(17.2 \%)\end{array}$ & $\begin{array}{c}99 \\
(39.6 \%)\end{array}$ & $\begin{array}{c}90 \\
(36 \%)\end{array}$ & $\begin{array}{c}10 \\
(4 \%)\end{array}$ & $\begin{array}{c}8 \\
(3.2 \%)\end{array}$ \\
\hline 06. & $\begin{array}{c}\text { Quality of the Nursing } \\
\text { Services }\end{array}$ & $\begin{array}{c}75 \\
(30 \%)\end{array}$ & $\begin{array}{c}92 \\
(36.8 \%)\end{array}$ & $\begin{array}{c}71 \\
(28.4 \%)\end{array}$ & $\begin{array}{c}10 \\
(4 \%)\end{array}$ & $\begin{array}{c}2 \\
(0.8 \%)\end{array}$ \\
\hline
\end{tabular}

(NOTE: 5-Very Satisfied, 4-Satisfied, 3-OK, 2-Unsatisfied, 1-Very Unsatisfied). 
Table 4: Patients satisfaction towards allied health care services and hospital infrastructure

\begin{tabular}{|c|c|c|c|c|c|c|}
\hline \multirow{2}{*}{ S.No } & \multirow{2}{*}{ Parameter } & \multicolumn{5}{|c|}{ Satisfaction Level } \\
\hline & & 5 & 4 & 3 & 2 & 1 \\
\hline \multicolumn{7}{|c|}{ Allied Health Care Services } \\
\hline 01 & Nutrition Services & $\begin{array}{c}130 \\
(52 \%)\end{array}$ & $\begin{array}{c}86 \\
(34.4 \%)\end{array}$ & $\begin{array}{c}33 \\
(13.2 \%)\end{array}$ & $\begin{array}{c}1 \\
(0.4 \%)\end{array}$ & 0 \\
\hline 02 & Laboratory Services & $\begin{array}{c}90 \\
(36 \%)\end{array}$ & $\begin{array}{c}134 \\
(53.6 \%)\end{array}$ & $\begin{array}{c}26 \\
(10.4 \%)\end{array}$ & 0 & 0 \\
\hline \multicolumn{7}{|c|}{ Hospital Infrastructure } \\
\hline 03 & $\begin{array}{c}\text { Cleanliness and } \\
\text { Hygiene }\end{array}$ & $\begin{array}{c}137 \\
(54.8 \%)\end{array}$ & $\begin{array}{c}98 \\
(39.2 \%)\end{array}$ & $\begin{array}{c}13 \\
(5.2 \%)\end{array}$ & $\begin{array}{c}2 \\
(0.8 \%)\end{array}$ & 0 \\
\hline 04 & $\begin{array}{l}\text { Availability of } \\
\text { Drinking Water }\end{array}$ & $\begin{array}{c}75 \\
(30 \%)\end{array}$ & $\begin{array}{c}125 \\
(50 \%)\end{array}$ & $\begin{array}{c}44 \\
(17.6 \%)\end{array}$ & $\begin{array}{c}3 \\
(1.2 \%)\end{array}$ & $\begin{array}{c}3 \\
(1.2 \%)\end{array}$ \\
\hline 05 & Sanitary Facilities & $\begin{array}{c}82 \\
(32.8 \%)\end{array}$ & $\begin{array}{c}132 \\
(52.8 \%)\end{array}$ & $\begin{array}{c}31 \\
(12.4 \%)\end{array}$ & $\begin{array}{c}4 \\
(1.6 \%)\end{array}$ & $\begin{array}{c}1 \\
(0.4 \%)\end{array}$ \\
\hline \multicolumn{7}{|c|}{ Other Services } \\
\hline 06 & Registration Process & $\begin{array}{c}15 \\
(06 \%)\end{array}$ & $\begin{array}{c}143 \\
(57.2 \%)\end{array}$ & $\begin{array}{c}80 \\
(32 \%)\end{array}$ & $\begin{array}{c}11 \\
(4.4 \%)\end{array}$ & $\begin{array}{c}1 \\
(0.4 \%)\end{array}$ \\
\hline 07 & $\begin{array}{l}\text { Monetary Expenses } \\
\text { on each visit }\end{array}$ & $\begin{array}{c}47 \\
(18.8 \%)\end{array}$ & $\begin{array}{c}82 \\
(32.8 \%)\end{array}$ & $\begin{array}{c}104 \\
(41.6 \%)\end{array}$ & $\begin{array}{c}10 \\
(04 \%)\end{array}$ & $\begin{array}{c}7 \\
(2.8 \%)\end{array}$ \\
\hline 08 & $\begin{array}{l}\text { Improvement in } \\
\text { Health condition }\end{array}$ & $\begin{array}{c}137 \\
(54.8 \%)\end{array}$ & $\begin{array}{c}90 \\
(36 \%)\end{array}$ & $\begin{array}{c}23 \\
(9.2 \%)\end{array}$ & 0 & 0 \\
\hline
\end{tabular}

(NOTE: 5-Very Satisfied, 4-Satisfied, 3-OK, 2-Unsatisfied, 1-Very Unsatisfied).

\begin{tabular}{|c|c|c|c|c|c|c|}
\hline \multirow[b]{2}{*}{ S.No: } & \multirow{2}{*}{$\begin{array}{l}\text { Paramedical } \\
\text { Services }\end{array}$} & \multicolumn{5}{|c|}{ Satisfaction Level } \\
\hline & & 5 & 4 & 3 & 2 & 1 \\
\hline 01. & $\begin{array}{c}\text { Pharmaceutical } \\
\text { Services }\end{array}$ & $50(20 \%)$ & $123(49.2 \%)$ & $68(27.2 \%)$ & $9(3.6 \%)$ & 0 \\
\hline 02. & Nursing Services & $109(43.6 \%)$ & $101(40.4 \%)$ & $38(15.2 \%)$ & $2(0.8 \%)$ & 0 \\
\hline 03. & $\begin{array}{l}\text { Nutrition } \\
\text { Services }\end{array}$ & $130(52 \%)$ & $86(34.4 \%)$ & $33(13.2 \%)$ & $1(0.4 \%)$ & 0 \\
\hline 04. & $\begin{array}{l}\text { Laboratory } \\
\text { Services }\end{array}$ & $90(36 \%)$ & $134(53.6 \%)$ & $26(10.4 \%)$ & 0 & 0 \\
\hline
\end{tabular}

(NOTE: 1-Very Unsatisfied, 2-Unsatisfied, 3-OK, 4-Satisfied, 5-Very Satisfied).

questionnaire regarding nursing care services found to be linked parallel with a study carried in Sri Lanka (Upul Senarathet al., 2011). ${ }^{15}$

The response of patient satisfaction on nursing care services in our study found similar to that of a study carried in healthcare settings of India (Suresh K. Sharma et al., 2013). ${ }^{16}$

The findings of our study about overall patients' satisfaction towards allied healthcare services and hospital amenities and infrastructure was found to be satisfactorial. The response of patient satisfaction on cleanliness, sanitary and water facilities was more satisfactorial as that of patient perception found in another study of Nethi Suresh Babu et al., 2012. ${ }^{17}$ The experience and perception of our study participants on the laboratory services was satisfactorial as similar to the study of Nethi Suresh Babu et al., 2012. ${ }^{17}$

In our study, patient dissatisfaction was only due to reason of time lapse in registration process, in dispensing for receiving medications and in laboratory which needs further look into the causes whether it is due to overburden of work or staff needs training towards this.

\section{CONCLUSION}

In conclusion, patient satisfaction can be affected by various issues and the healthcare organizations have to notice those areas influencing patient satisfaction to improve their quality of the services and health outcomes. 


\section{ACKNOWLEDGEMENT}

The authors would like to thank Dr. K. Sudheer Kumar-Medical Director, RDT Hospitals Bathalapalli, Ms. G. Little Flower-Nursing Superintendent, RDT Hospitals Bathalapalli and Mrs. G. Venkata SrivaniChief Pharmacist, RDT Hospitals Bathalapalli for their valuable guidance and constant support.

\section{CONFLICT OF INTEREST}

The author declares no conflict of interest.

\section{ABBREVIATIONS USED}

MMW: $\quad$ Male Medical Ward

FMW: $\quad$ Female Medical Ward

MSW: Male Surgical Ward

FSW: $\quad$ Female Surgical Ward

\section{REFERENCES}

1. Schommer JC, Kucukalsan SN. Measuring patient satisfaction with pharmaceutical services. Am J. Health. Syst Pharm. 1997; 54(23):2721-32.

2. Larson LN, Rovers JP,Mackeigan LD. Patient satisfaction with pharmaceutical care: Update of a validated instrument. J Amer Pharm Assoc. 2002; 42(1):44-50.

3. Pascoe GC. Patient satisfaction in primary healthcare: a literature review and analysis. Evaluation and Program Planning. 1983; 6(3-4):185-210.

4. Hall J, Dornan M. Meta-analysis of satisfaction with medical care: Description of research domain and analysis of overall satisfaction levels. Soc. Sci. Med.1998; 21(6):637-44.
5. Mira JJ, Aranaz J. La satisfacióndelpacientecomounamedida del resulado de la atención sanitaria. Med. Clin. (Barc).2000; 114(3):26-33.

6. Fitzpatrick R. The assessment of patient satisfaction. In: Jenkinson C, ed. Assessment and evaluation of health and medical care. Buckingham: Open University Press.1997;1st ed. 4(1): 85-101.

7. Yogesh PP, Gaurav R,Satyanarayana C. Factors affecting in-patient satisfaction in hospital: A case study. Int. J. Mgmt Res. \& Bus. Strat. 2014; 3(3):181-187

8. Taylor C, Lillis C, Lemone P. Fundamentals of nursing. $3^{\text {rd }}$ ed. Lippincott, 1977: 110-112.

9. Mufti S, Qadri GJ, Tabish SA, Mufti S,Riyaz R. Patient's perception of nursing care at a large teaching hospital in India. International Journal of Health Sciences. 2008; 2(2):92-100.

10. Aharony L, Strasser S. Patient satisfaction: what we know about and what we know about and what we still need to explore. Med Care Rev. 1993;50(1): 49-79.

11. Jackson J, Chamberlin J, Kroenke K. Predictors of patient satisfaction. SocSci Med 2001;52(4):609-20.

12. Sadiq SM. Service quality in hospitals: More favourable than you might think. Managing Service Quality (Emerald-MCB). 2003;13(3):197-206

13. Khudair IF, Raza SA. Measuring patients' satisfaction with pharmaceutical services at a public hospital in Qatar. Int J Healthcare QualAssur. 2013; 26(5):398-419.

14. Sumeet S, Paramjeet K, Ritu R. Patient satisfaction levels in a tertiary care medical college hospital in Punjab, North India. Int J Res Dev Health. November 2013; 1(4):172-82.

15. Senarath U, Gunawardena NS. Development of an Instrument to Measure Patient Perception of the Quality of Nursing Care and Related Hospital Services at the National Hospital of Sri Lanka. Asian Nursing Research. June2011;5(2):71-80

16. Suresh KS, Pawan KK. Patient Satisfaction with Nursing Care in Public and Private Hospitals. Nursing and Midwifery Research Journal. 2013; 9(3):131-41.

17. Nethi SB, Sreenivas T. A study on patient satisfaction in hospitals. Int. J. Mgmt Res. \& Bus. Strat. 2012; 1(1):101-118. 